\title{
Assessment of Benzophenanthridine and Protopine Alkaloids in Broiler Challenged and Not by Salmonella Heidelberg
} http://dx.doi.org/10.1590/1806-9061-2015-0045

-Author(s)

\section{Previato do Amaral PFG'}

Otutumi LK'

Rodrigues $\mathrm{GV}^{\prime}$

Lima ET"

Fernandes JIM"

Vendrame $A^{\prime \prime}$

Mezalira TS'

Suenaga $\mathrm{SS}^{\prime}$

Sestari DAO'

Cestari IED'

Martins LA

Paranaense University - UNIPAR, Umuarama, Paraná, Brazil.

" Federal University of Paraná - UFPR, Palotina, Paraná, Brazil.

\section{ABSTRACT}

Salmonellosis is a globally important zoonosis, and Salmonella Heidelberg is one of the most prevalent serovars in poultry production worldwide, as well as in food poisoning cases. Antimicrobial drugs were previously widely used to face health challenges in animal production; however, since their ban as performance enhancers, many alternative strategies have been proposed. One of these strategies is the use of plant extracts, such as those containing the alkaloids benzophenanthridine and protopine. These compounds have antimicrobial, anti-inflammatory, immunomodulation, and nutritional effects. The objective of the present study was to evaluate the effects of the supply of a product containing benzophenanthridine and protopine (Sangrovit ${ }^{\circledR} W S 100 \mathrm{~g} / 1000 \mathrm{~L}$ of drinking water) to broilers during different rearing periods 1-21, 1-6 and 6-21 days of age challenged or not with Salmonella Heidelberg at six days of age. There was no effect of the product on the performance, jejunal morphometry, cecal goblet cell counts, or control of Salmonella spp. in broilers challenged or not with Salmonella Heidelberg. However, the group receiving the alkaloids from 1 to 21 days of age, compared with the control group, presented a numerical difference of 28 points in productive efficiency index, which directly impacts live production cost of live broiler, representing savings of $R \$ 0.11 / \mathrm{kg}$ of meat produced.

\section{INTRODUCTION}

According to Lanzarin (2012), bacteria of the genus Salmonella are among the most important pathogens affecting the poultry industry. The presence of Salmonella spp. on the skin, feathers, feet, cloaca and digestive tract of poultry is a significant source of carcass contamination in the processing plant, and therefore may pose food safety risks to the public (Rezende et al., 2005).

Some serotypes, such as $S$. Typhimurium and $S$. Enteritidis, were the main focus of Salmonella control in the poultry industry, but new serotypes, including S. Heidelberg, S. Agona, and S. Senftenberg, have been increasing isolated from poultry in different regions of Brazil (Lanzarin, 2012). Dickel (2004) evaluating hygiene and health parameters in three broiler processing plants in southern Brazil, isolated S. Heidelberg in $63.9 \%$, S. Enteritidis in $31.9 \%$, S. Worthington in $2.1 \%$, and $S$. Tennessee in $2.1 \%$ of the studied samples. The Public Health Agency of Canada (2007) reports that among the Salmonella paratyphi serovars that infect humans, $\mathrm{S}$. Heidelberg seems to be the most invasive and causes the most severe disease symptoms.

Santana et al. (2011) mentioned that due the high demand for poultry products, the broiler industry has aimed at obtaining maximum production at the shortest production time and have applied antimicrobial products in therapeutics and prophylaxis, as well as for performance enhancement, to maximize productivity. 
Previato do Amaral PFG, Otutumi LK, Rodrigues GV, Lima ET, Fernandes JIM, Vendrame A, Mezalira TS, Suenaga SS, Sestari DAO, Cestari IED, Martins LA
Assessment of Benzophenanthridine and Protopine Alkaloids in Broiler Challenged and Not by Salmonella Heidelberg
Since the ban on the use of antimicrobials as performance enhancers in the European Union in 2006, there has been increasing research on alternative therapeutic products (Griggs \& Jacob, 2005). The strategic use of dietary supplementation with plant extracts in food animals has shown many benefits through its active properties (Vieira et al, 2008a; Vieira et al, 2008b; Hernández et al, 2004).

Oliveira (2012) reported that benzophenanthridine (sanguinarine and chelerythrine) and protopine (protopine and alocryptopine) alkaloids are the active principles extracted from Macleaya cordata. According to Kosina et al. (2004), sanguinarine and chelerytrine have antimicrobial, anti-inflammatory, local anesthetic and sympatholytic effects. Pickler (2011) described the efficiency of benzophenanthridine and protopine alkaloids in reducing the isolation of Salmonella Enteritidis in the crop and ceca of broilers seven days after inoculation. In the study of Salvador et al. (2014), those alkaloids efficiently controlled Salmonella Typhimurium in the crop, duodenum and gizzard of broilers.

Benzophenanthridine and protopine alkaloids also have nutritional effects, as they increase the availability of amino acids. Their active principles block the activity of decarboxylase amino acid aromatic enzymes present in the intestinal lumen, thus increasing protein retention, consequently promoting better performance (Dršata et al., 1996). In addition, Schmeller et al. (1997) reported that sanguinarine has affinity with the $5-\mathrm{HT}_{2}$ serotonin receptor, a neurotransmitter with modulatory effect on the appetite (Tarazi et al., 2010), which may have a positive impact on feed intake.

Therefore, the objective of this study was to evaluate the effect of benzophenanthridine and protopine alkaloids (BPA) supplied in drinking water of broilers challenged or not with Salmonella Heidelberg on their growth performance, jejunal morphometry, cecal goblet cell counts, and of Salmonella spp. control.

\section{MATERIAL AND METHODS}

The experimental procedures were approved by the Ethics Committee and Research Involving Animal Experiments (Comitê de Ética e Pesquisa Envolvendo Experimentação Animal - (EPEEA) of Paranaense University under protocol number 25231/2014.

\section{Birds, Experimental Design, Environment and Diet}

The experiment was conducted on July 3-24, 2014, at the animal laboratory of the Federal University of Paraná, Palotina campus, state of Paraná, Brazil.
A total of 480 male Cobb 500 broilers were distributed into eight treatments, with four repetitions with 15 birds each. Birds were challenged or not by Salmonella Heidelberg at six days of age. The treatments consisted of: $T_{1}$ - negative control group, no BPA in the drinking water and not challenged; $T_{2}$ - positive control group, drinking water with BPA and challenged; $T_{3}$ - positive test group, drinking water with BPA in the period of one to 21 days and challenged; $T_{4}$ - negative test group, drinking water with BPA in the period of one to 21 days and not challenged; $T_{5}$ - positive test group, drinking water with BPA in the period of one to six days and challenged; $T_{6}$ - negative test group, drinking water with BPA in the period of one to six days and not challenged; $T_{7}$ - positive test group, drinking water with BPA in the period of six to 21 days and challenged; $\mathrm{T}_{8}$ - negative test group, drinking water with BPA in the period of six to 21 days and not challenged.

Broilers were housed from one to 21 days of age in cages with autoclaved poultry litter in a room maintained at the comfort temperature for this age, according to the company's genetic manual (Cobb-Vantress, 2009). Water and feed were supplied ad libitum. Birds were fed a starter diet with an anticoccidial drug (salinomycin at $66 \mathrm{ppm}$ ) and no performance enhancers. The ingredients and calculated composition of the experimental diet is shown in Table 1.

\section{Product Assessed}

Sangrovit ${ }^{\circledR}$ WS is a phytogenic feed additive consisting of benzophenanthridine (sanguinarine and chelerytrine) and protopine (protopine and allocryptopine) alkaloids extracted from a Macleaya cordata extract at the concentration of $1.65 \%$. It is recommended for the maintenance of intestinal integrity. It is sold in 1-kg boxes containing $50-\mathrm{g}$ sachets. The recommended dose is $100 \mathrm{~g}$ of product for $1000 \mathrm{~L}$ of drinking water $(100 \mathrm{ppm}$ of product, or $1.6 \mathrm{ppm}$ of alkaloids).

\section{Growth Performance}

In order to evaluate growth performance, feed offer, remainder of feed, and broilers were weekly weighed for the calculation of feed intake, weight gain, feed conversion ratio, and production efficiency index. The birds that died during the experiment were also weighed for the correction of weight gain, feed intake and viability.

\section{Challenge Strain and Inoculation}

The Salmonella Heidelberg inoculum, at a concentration of $10^{5} \mathrm{CFU} / \mathrm{mL}$, was prepared at Mercolab Lab- 
Previato do Amaral PFG, Otutumi LK, Rodrigues GV, Lima ET, Fernandes JIM, Vendrame A, Mezalira TS, Suenaga SS, Sestari DAO, Cestari IED, Martins LA

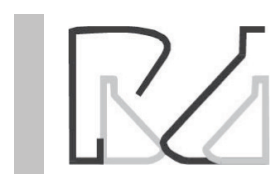

Assessment of Benzophenanthridine and Protopine Alkaloids in Broiler Challenged and Not by Salmonella Heidelberg oratory, located in Cascavel, state of Paraná, Brazil, according to the methodology described by the Brazilian Health Surveillance Agency (ANVISA) (2003).

Table 1 - Ingredients and calculated composition of the diet offered to the broilers from one to 21 days of age.

\begin{tabular}{|c|c|}
\hline Ingredients & $(\%)$ \\
\hline Corn & 56.000 \\
\hline Soybean meal & 36.480 \\
\hline Vitamin premix ${ }^{1}$ & 0.120 \\
\hline Mineral premix ${ }^{1}$ & 0.100 \\
\hline Salt & 0.440 \\
\hline Soybean oil & 4.400 \\
\hline Salinomycin & 0.055 \\
\hline Antioxidant & 0.010 \\
\hline L-lysine & 0.266 \\
\hline L-threonine & 0.091 \\
\hline Methionine - MHA & 0.400 \\
\hline Sodium bicarbonate & 0.100 \\
\hline Limestone & 1.440 \\
\hline Mono-dicalcium phosphate & 1.680 \\
\hline Choline chloride & 0.070 \\
\hline TOTAL & 100.000 \\
\hline \multicolumn{2}{|c|}{ Calculated Nutritional Composition } \\
\hline Metabolizable energy (kcal/kg) & 3.099 \\
\hline Crude protein (\%) & 20.997 \\
\hline Total calcium (\%) & 1.001 \\
\hline Phosphorous available (\%) & 0.479 \\
\hline Digestible lysine (\%) & 1.200 \\
\hline Digestible methionine (\%) & 0.632 \\
\hline Digestible tryptophan (\%) & 0.209 \\
\hline Digestible threonine (\%) & 0.744 \\
\hline
\end{tabular}

'Guarantee levels/kg feed: Copper (Cu) 8.000 mg; Iron (Fe) 200.858 mg; lodine (I) 1.008 mg; Manganese (Mn) 79.800 mg; Selenium (Se) 0.297 mg; Zinc (Zn) 79.002 mg; Vitamin A 12,129.600 Ul; Vitamin D3 2,462.400 Ul; Vitamin E 36.158 Ul; Vitamin K3 2.402 mg; Vitamin B1 (Thiamine) 3.000 mg; Vitamin B2 (Riboflavin) 7.126 mg; Vitamin B6 (Pyridoxine) 3.600 mg; Vitamin B12 (Cyanocobalamin) 0.018 mg; Folic Acid 1.200 mg; Pantothenic Acid 14.400 mg; Niacin 48,000 mg; Biotin (Vitamin H) $0.120 \mathrm{mg}$; Choline 1,695.244 mg.

At six days of age, all birds in the $\mathrm{T}_{2}$ (Control, $\mathrm{SH}$ ), $\mathrm{T}_{3}$ (BPA 1-21d, SH), $\mathrm{T}_{5}$ (BPA 1- $6 \mathrm{~d}, \mathrm{SH}$ ) and $\mathrm{T}_{7}$ (BPA 6-21d, SH) treatments were orally inoculated with 1 $\mathrm{mL}$ of $\mathrm{S}$. Heidelberg solution at the concentration of $10^{5} \mathrm{CFU} / \mathrm{mL}$.

\section{Microbiological Analysis}

Two birds per experimental unit were randomly selected and euthanized under anesthesia (eight birds per treatment) $48 \mathrm{~h}$ after the inoculation with $S$. Heidelberg. The protocol was pre-anesthesia with intramuscular xylazine at $4 \mathrm{mg} / \mathrm{kg}$, and euthanasia with intravenous thiopental at $25 \mathrm{mg} / \mathrm{kg}$.

Birds were necropsied and their ceca were aseptically collected for Salmonella spp. count, performed according to the methodology described by Pickler et al. (2012). Typical colonies Salmonella were submitted to serology using polyvalent serum for confirmation. The count results were transformed in $\log _{10}$ for statistical analysis.

Cloacal swabs were aseptically collected for the isolation of Salmonella spp., following the methodology described by Almeida (2013). Colonies with characteristic Salmonella biochemistry results were submitted to the agglutination test in plates with anti-flagellar $(\mathrm{H})$ and anti-somatic $(\mathrm{O})$ polyvalent sera. The same procedures were applied in 21-d-old birds.

Colony counts were performed according to Normative Instruction no. 62 (BRASIL, 2003), which establishes official analytical methods for microbiological analyses for the control of animal products and water, issued on August 26, 2003.

\section{Intestine Morphometry and Quantitative Analysis}

On day 21, two birds per experimental unit (eight birds per treatment) were randomly selected and euthanized according to the protocol described above. At necropsy, fragments of the jejunum and cecum were collected and longitudinally open by the mesenteric border, and fixed in 10\% buffered formalin solution for $24 \mathrm{~h}$. Semi-serial $4 \mu \mathrm{m}$ sections, perpendicular to the long axis of the jejunum and cecum, were obtained. Cecum samples were dyed with Alcian Blue pH 2.5 for goblet cell count (non-sulfated and sulfated acid mucins). Goblet cell were count in the ceca because it is the preferential intestinal segment of Salmonella Heidelberg replication, according to Shivaprasad (1997). Jejunal samples were dyed with hematoxylin and eosin for the morphometric analysis. Images were obtained by using a digital camera ${ }^{1}$ attached to a trinocular light microscope at $4 x$ magnification for the jejunum and 20x magnification for the cecum. The camera was connected to an image analysis system². The height of 60 villi and the crypt of 60 crypts were measured in the jejunum and goblet cells were counted in 15 villi of the cecum of each bird.

\section{Statistical Analysis}

Data were tested for normality (Shapiro-Wilk test) and homogeneity of variance (Levene test). As these assumptions were satisfied, the studied parameters were submitted to the analysis of variance (ANOVA). Colony forming units (CFU) of Salmonella spp. were transformed in $\log _{10}$ before being submitted to ANOVA. Morphometry data were evaluated by analysis

\footnotetext{
Moticam 2000, 2.0 Megapixel ${ }^{\circledR}$

${ }^{2}$ Moticlmages Plus, version $2.0^{\circledR}$
} 
Previato do Amaral PFG, Otutumi LK, Rodrigues GV, Lima ET, Fernandes JIM, Vendrame A, Mezalira TS, Suenaga SS, Sestari DAO, Cestari IED, Martins LA
Assessment of Benzophenanthridine and Protopine Alkaloids in Broiler Challenged and Not by Salmonella Heidelberg of variance (ANOVA), and when statistically different, means were compared Tukey's test. Median goblet cell counts were analyzed by the Kruskal-Wallis test. A $5 \%$ significance level was applied to all tests. Analyses were performed using the used was IBM SPSS v. 21.0 statistical program.

\section{RESULTS AND DISCUSSION}

No body weight differences were detected among broilers receiving or not benzophenanthridine and protopine alkaloids (BPA) in the drinking water, or challenged or not by Salmonella Heidelberg (Table 2 ) on days 7 and 14 . However, on day 21, the birds receiving BPA for the period of one to 21 days of age (BPA 1-21d) were heavier $(p<0.05)$ compared with those receiving BPA from one to six days of age and challenged with $S$. Heidelber $g$ at six days of age (BPA 1- $6 \mathrm{~d}$, SH) (Table 2).

Table 2 - Means \pm standard error of the body weight (BW, kg) of 7-, 14-, and 21-d-old broilers receiving or not benzophenanthridine and protopine alkaloids (BPA) in the drinking water, and challenged or not by Salmonella Heidelberg (SH) at six days of age.

\begin{tabular}{lccc}
\hline Treatments & BW day 7 & BW day 14 & BW day 21 \\
\hline Negative control & $0.152 \pm 0.004$ & $0.401 \pm 0.007$ & $0.779^{\mathrm{ab}} \pm 0.012$ \\
Positive control & $0.163 \pm 0.002$ & $0.404 \pm 0.007$ & $0.789^{\mathrm{ab}} \pm 0.036$ \\
BPA 1-21d, SH & $0.158 \pm 0.002$ & $0.391 \pm 0.017$ & $0.769^{\mathrm{ab}} \pm 0.022$ \\
BPA 1-21d & $0.164 \pm 0.003$ & $0.422 \pm 0.010$ & $0.822^{\mathrm{a}} \pm 0.011$ \\
BPA 1-6 d, SH & $0.156 \pm 0.001$ & $0.404 \pm 0.006$ & $0.748^{\mathrm{b}} \pm 0.009$ \\
BPA 1-6 d & $0.155 \pm 0.003$ & $0.399 \pm 0.012$ & $0.789^{\mathrm{ab}} \pm 0.018$ \\
BPA 6-21d, SH & $0.158 \pm 0.002$ & $0.398 \pm 0.012$ & $0.757^{\mathrm{ab}} \pm 0.011$ \\
BPA 6-21d & $0.158 \pm 0.004$ & $0.407 \pm 0.028$ & $0.762^{\mathrm{ab}} \pm 0.019$ \\
\hline p value & $0.073^{*}$ & $0.896^{*}$ & 0.040 \\
CV \% & 3.83 & 6.54 & 4.40 \\
\hline
\end{tabular}

*Not significant

Means followed by different letters in the same column are statistically by Tukey's test. $\mathrm{CV}$ : Coefficient of variation

Zdunczyk et al. (2010), Vieira et al. (2008a), and Vieira et al. (2008b) when assessing the performance of broilers treated with BPA, but not submitted to health challenges. Zdunczyk et al. (2010) did not observe any differences $(p>0.05)$ in the body weight of BPA-treated broilers relative to the controls neither 8 nor at 21 days of age. The results obtained in the present study with BPA supplementation relative the control group (Table 2), regardless of the period of supplementation, support those findings.

On the other hand, in the study of Vieira et al. (2008a), 21-d-old broilers receiving 50 ppm of a product containing BPA in the drinking water were heavier than the controls. Moreover, Vieira et al. (2008b), when evaluating different levels $(0,12.5$,
$25,37.5$, and $50 \mathrm{ppm}$ ) of a BPA product added to the feed as a performance enhancer, observed a higher weight gain in 21-d-old broilers receiving 50 ppm BPA compared with the controls.

Weight gain and feed conversion ration were not influenced by the treatments ( $p>0.05$ ) in the periods of one to seven days. Although there was a higher feed intake in the birds from group treated with BPA during the period of one to 21 days of age and not challenged (BPA 1-21d) when compared to the birds of group treated with BPA during the same period and challenged by Salmonella Heidelberg at six days of age (BPA 1-21d, SH) (Table 3).

Table 3 - Means \pm standard error of weight gain $(\mathrm{kg})$, feed intake $(\mathrm{kg})$ and feed conversion ratio $(\mathrm{kg} / \mathrm{kg})$ of broilers in the period of one to seven days receiving or not benzophenanthridine and protopine alkaloids (BPA) in the drinking water, and challenged or not by Salmonella Heidelberg (SH) at six days of age.

\begin{tabular}{lccc}
\hline Treatments & $\begin{array}{c}\text { Weight gain } \\
(\mathrm{kg})\end{array}$ & $\begin{array}{c}\text { Feed intake } \\
(\mathrm{kg})\end{array}$ & $\begin{array}{c}\text { Feed conversion } \\
(\mathrm{kg})\end{array}$ \\
\hline Negative control & $0.117 \pm 0.003$ & $0.134^{\mathrm{ab}} \pm 0.003$ & $1.163 \pm 0.022$ \\
Positive Control & $0.127 \pm 0.002$ & $0.138^{\mathrm{ab}} \pm 0.003$ & $1.097 \pm 0.016$ \\
BPA 1-21d, SH & $0.122 \pm 0.002$ & $0.132^{\mathrm{b}} \pm 0.003$ & $1.084 \pm 0.016$ \\
BPA 1-21d & $0.128 \pm 0.003$ & $0.146^{\mathrm{a}} \pm 0.003$ & $1.139 \pm 0.020$ \\
BPA 1-6 d, SH & $0.120 \pm 0.001$ & $0.137^{\mathrm{ab}} \pm 0.002$ & $1.143 \pm 0.018$ \\
BPA 1-6 d & $0.118 \pm 0.003$ & $0.137^{\mathrm{ab}} \pm 0.001$ & $1.163 \pm 0.025$ \\
BPA 6-21d, SH & $0.122 \pm 0.002$ & $0.135^{\mathrm{ab}} \pm 0.002$ & $1.106 \pm 0.008$ \\
BPA 6-21d & $0.122 \pm 0.003$ & $0.138^{\mathrm{ab}} \pm 0.003$ & $1.138 \pm 0.013$ \\
\hline p value & $0.060^{*}$ & 0.047 & $0.074^{*}$ \\
CV\% & 4.82 & 4.46 & 3.74 \\
\hline
\end{tabular}

*Not significant

Means followed by different letters in the same column are statistically by Tukey's test. $\mathrm{CV}$ : Coefficient of variation

The results of the present study are consistent with Vieira et al. (2008b), who evaluated BPA supplementation in the feed of broilers not submitted to health challenge and did not find any feed conversion ratio differences $(p>0.05)$ between the group treated with BPA and the control group in the period of one to seven days of age. However, it is important to emphasize that in the present study, birds in treatments $T_{2}, T_{3^{\prime}} T_{5}$ and $T_{7}$ were challenged with $10^{5} \mathrm{CFU} / \mathrm{mL}$ Salmonella Heidelberg at six days of age.

During the period of one to 21 days of age, the group treated with BPA from one to 21 days and not challenged (BPA 1-21d) presented higher weight gain and feed intake than the group supplied with BPA from one to six days of age and challenged by Salmonella Heidelberg (BPA 1-6d, SH). However, no feed conversion ratio differences were detected among treatments in the period of one to 21 days of age (Table 4). 
Previato do Amaral PFG, Otutumi LK, Rodrigues GV, Lima ET, Fernandes JIM, Vendrame A, Mezalira TS, Suenaga SS, Sestari DAO, Cestari IED, Martins LA

\section{Assessment of Benzophenanthridine and Protopine Alkaloids in Broiler Challenged and Not by Salmonella Heidelberg}

Table 4 - Means \pm standard error of weight gain $(\mathrm{kg})$, feed intake $(\mathrm{kg})$ and feed conversion $(\mathrm{kg} / \mathrm{kg})$ and production efficiency index of 1- to 21-d-old broilers receiving or not benzophenanthridine and protopine alkaloids (BPA) in the drinking water, and challenged or not by Salmonella Heidelberg $(\mathrm{SH})$ at six days of age.

\begin{tabular}{lcccc}
\hline Treatments & Weight gain $(\mathrm{kg})$ & Feed intake $(\mathrm{kg})$ & Feed conversion $(\mathrm{kg})$ & Production efficiency index \\
\hline Negative control & $0.743^{\mathrm{ab}} \pm 0.012$ & $1.020^{\mathrm{ab}} \pm 0.014$ & $1.376 \pm 0.023$ & $260.75^{\mathrm{ab}} \pm 4.768$ \\
Positive Control & $0.753^{\mathrm{ab}} \pm 0.003$ & $1.048^{\mathrm{ab}} \pm 0.012$ & $1.392 \pm 0.018$ & $265.25^{\mathrm{ab}} \pm 3.198$ \\
BPA 1-21d, SH & $0.733^{\mathrm{ab}} \pm 0.022$ & $0.999^{\mathrm{ab}} \pm 0.029$ & $1.363 \pm 0.006$ & $268.75^{\mathrm{ab}} \pm 8.673$ \\
BPA 1-21d & $0.785^{\mathrm{a}} \pm 0.011$ & $1.063^{\mathrm{a}} \pm 0.013$ & $1.355 \pm 0.008$ & $289.00^{\mathrm{a}} \pm 5.083$ \\
BPA 1-6 d, SH & $0.712^{\mathrm{b}} \pm 0.009$ & $0.970^{\mathrm{b}} \pm 0.009$ & $1.358 \pm 0.009$ & $262.25^{\mathrm{ab}} \pm 3.705$ \\
BPA 1-6 d & $0.752^{\mathrm{ab}} \pm 0.018$ & $1.044^{\mathrm{ab}} \pm 0.010$ & $1.390 \pm 0.027$ & $267.25^{\mathrm{ab}} \pm 13.961$ \\
BPA 6-21d, SH & $0.721^{\mathrm{ab}} \pm 0.012$ & $1.010^{\mathrm{ab}} \pm 0.028$ & $1.442 \pm 0.052$ & $231.00^{\mathrm{b}} \pm 13.862$ \\
BPA 6-21d & $0.726^{\mathrm{ab}} \pm 0.002$ & $1.050^{\mathrm{ab}} \pm 0.023$ & $1.447 \pm 0.053$ & $247.50^{\mathrm{ab}} \pm 11.990$ \\
\hline P value & 0.041 & 0.029 & $0.243^{*}$ & 0.013 \\
CV\% & 4.56 & 4.34 & 4.56 & 8.71 \\
\hline
\end{tabular}

*Not significant

Means followed by different letters in the same column are statistically by Tukey's test.

CV: Coefficient of variation

The production efficiency index of the group treated with BPA from one to 21 days of age and not challenged (BPA 1-21d) was higher compared with the group supplied with BPA from six to 21 days of age and challenged with $S$. Heidelberg (BPA 6-21, SH).

The results presented (weight gain, feed intake, feed conversion and production efficiency index) in Table 4 show that there were no differences $(p>0.05)$ between the groups challenged or not by $S$. Heidelberg at six days of age receiving BPA for the same periods. According to Muniz (2014), this could be explained by the adaptation and balance of paratific salmonelas serovars, such as Heidelberg, living in the birds.

Santiago et al. (2014), evaluating the effects of a Macleaya cordata extract (BPA source) included at $50 \mathrm{ppm}$ in the feed of broilers challenged and not challenged with $0.5 \mathrm{~mL}$ Salmonella Typhimurium (108 $\mathrm{CFU} / \mathrm{mL}$ ) (Salmonella paratyphiserovar), observed higher daily weight gain in the groups treated (independent of challenge) and in non-challenged control group relative to the challenged group not fed BPA.

Vieira et al. (2008b), in the absence of health challenge, found a better feed conversion ratio in the group fed 37.5 ppm BPA relative to the control group in the period of one to 35 days of age. However, at the dose of 50 ppm, no differences were detected. This was also observed by Santiago et al. (2014), but in the presence of a health challenge. Zdunczyk et al. (2010), evaluating the inclusion of $30 \mathrm{ppm}$ of a product containing BPA in the feed of 1- to 35-d-old broilers, in the absence of challenge, did not find any feed conversion ratio differences $(p>0.05)$.

According to Niewold (2007), the performance enhancement effects of antimicrobial drugs in is mediated by anti-inflammatory mechanisms. Kosina et al.
(2004) reported that benzophenanthridine alkaloids (sanguinarine and chelerytrine) exhibit antimicrobial and anti-inflammatory effects, whereas Vieira et al. (2008b) emphasized that the combination of these effects explains the benefits of BPA to animal performance. Dršata et al. (1996) mentioned that the BPA increases amino acids availability by blocking the activity of aromatic amino acid decarboxylase enzymes present in the intestinal lumen, improving protein retention, and consequently, better performance.

However, in the present study, performance (weight gain, feed intake, feed conversion and production efficiency index) of the birds that consumed the alkaloids was not different ( $p>0.05$ ) compared with the that of the control groups. Nonetheless, production efficiency index presented 28.25 points numerical difference, which has a direct impact on the cost of live broilers. This difference, according to the current database of an integration in the Northwestern region in the state of Paraná, represents savings of RS 0.1106/ $\mathrm{kg}$ in the live cost of broilers consuming BPA from one to 21 days of age. Considering that 120,000 birds 42-d-old broilers weighing $2.5 \mathrm{~kg}$ are processed daily, on average, this represents savings of $R \$ 33,180$ per processing day.

No feed intake differences ( $p>0.05$ ) were found between the groups treated with BPA and the negative control group (Table 4). Similarly, Vieira et al. (2008b), in the absence of health challenge, did not detect any feed intake difference among BPA doses $(0,12.5$, 25, 37.5 and 50 ppm). According to Schmeller et al. (1997), sanguinarine has affinity for the receptor of $5-\mathrm{HT}_{2}$ serotonin, a neurotransmitter with modulatory effect on appetite and related to satiety (Tarazi et al., 2010), resulting in a positive impact on the average feed intake. 
Previato do Amaral PFG, Otutumi LK, Rodrigues GV, Lima ET, Fernandes JIM, Vendrame A, Mezalira TS, Suenaga SS, Sestari DAO, Cestari IED, Martins LA

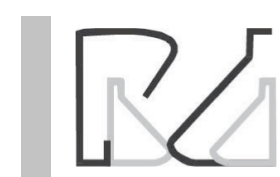

Jejunal morphometry (villus height, crypt depth and villus:crypt ratio) measured in 21-d-old broilers was not different among the treatments (Table 5).

These results are in agreement with Vieira et al. (2008a), evaluating the effects of BPA (starter feed with $50 \mathrm{ppm}$, and grower and finisher feed with 25 ppm of the product) on the villus height and crypt depth, did not find any found differences ( $p>0.05$ ) among the groups treated with BPA and the control group at 42 days of age. On the other hand, Pickler et al. (2013), studying the effect of BPA supplied in the drinking water (100 ppm of product) for the control of Salmonella Enteritidis found lower $(p<0.05)$ villus height and crypt depth in the jejunum of challenged broilers receiving BPA compared with the control group, but no differences in jejunal villus:crypt ratio or goblet cell count in the ceca. Likewise, Jankowski et al. (2009) observed that broilers fed with a diet containing $20 \mathrm{ppm}$ of a BPA product presented a significant reduction of villus height compared with the control group. Ferreira et al. (2006), investigating the effects of BPA added to vegetarian diets (starter feed with 50 ppm, and grower and finisher feeds with $25 \mathrm{ppm}$ of product) also observed that lower crypt depth in the BPA-fed groups relative to the control group.

Villus height and crypt depth are reduced when broilers are reared in a pathogen-free environment due to the balance of the intestinal microbiota (Cook \& Bird, 1973). This indicates that the integrity of the intestinal mucosa allows adequate nutrient digestion and absorption, and therefore compensatory hypertrophy and hyperplasia of villi and crypt observed when the mucosa is damaged, such as in the presence of health challenges, are not required. Therefore, the low health challenge of the rearing environment in
Assessment of Benzophenanthridine and Protopine Alkaloids in Broiler Challenged and Not by Salmonella Heidelberg

the present study may explain the lack of differences in the jejunal morphometry results, as well as the good performance overall live performance and viability (86.67 to $100 \%$ ). Santin et al. (2001) had previously reported a positive correlation among villus height, villus surface area, nutrient absorption, and performance of broilers.

According to Macari (1999), intestinal absorption capacity is directly proportional to villus number, size, and surface area available for absorption. This shows that the evaluation of a single parameter is not sufficient to demonstrate the absorptive potential of the intestine. In the present study, villus height, crypt depth, and villus:crypt ratio were assessed and no significant differences were observed among treatments. Vieira et al. (2008a) reported that villus measurements are commonly used to support the effects of nutrients on the gastrointestinal physiology, but the correlation between live performance and villus height or crypt depth is often not significant.

Goblet cell (producing non-sulfated acid mucins) counts in cecal villi of 21-d-old was not different among treatments (Table 6).

Although higher villi are related with better nutrient absorption under experimental conditions in the absence of challenge, the types of cells present in the villi are as important as their height (Pickler et al., 2013). Goblet cells secrete glycoproteins (mucus), which are responsible for protecting the intestinal epithelium against dietary abrasive agents and pathogens, as well as participating in the absorption of nutrients (Pickler et al. 2011; Pickler et al., 2013).

According to Pickler et al. (2011), mucus participated in the non-specific immune response as the expression of goblet increases under challenge

Table 5 - Means \pm standard error of villus height $(\mu \mathrm{m})$, crypt depth $(\mu \mathrm{m})$ and villus:crypt ratio $(\mu \mathrm{m} / \mu \mathrm{m})$ in the jejunum of 21-d-old broilers receiving or not benzophenanthridine and protopine alkaloids (BPA) in the drinking water, and challenged or not by Salmonella Heidelberg $(\mathrm{SH})$ at six days of age.

\begin{tabular}{lccc}
\hline Treatments & Villus height $(\mu \mathrm{m})$ & Crypt depth $(\mu \mathrm{m})$ & Villus:crypt $(\mu \mathrm{m} / \mu \mathrm{m})$ \\
\hline Negative control & $633.800 \pm 176.223$ & $175.599 \pm 27.964$ & $5.420 \pm 0.964$ \\
Positive Control & $882.608 \pm 95.603$ & $124.603 \pm 4.422$ & $7.100 \pm 0.776$ \\
BPA 1-21d, SH & $869.966 \pm 47.889$ & $130.009 \pm 4.920$ & $6.712 \pm 0.413$ \\
BPA 1-21d & $899.677 \pm 15.021$ & $125.531 \pm 4.967$ & $7.193 \pm 0.244$ \\
BPA 1-6 d, SH & $932.718 \pm 52.460$ & $140.767 \pm 23.297$ & $7.002 \pm 0.772$ \\
BPA 1-6 d & $951.666 \pm 15.367$ & $162.491 \pm 13.479$ & $6.000 \pm 0.590$ \\
BPA 6-21d, SH & $917.497 \pm 52.846$ & $132.813 \pm 6.981$ & $6.965 \pm 0.515$ \\
BPA 6-21d & $908.673 \pm 43.249$ & $156.930 \pm 24.543$ & $6.138 \pm 0.785$ \\
\hline p value & $0.180^{*}$ & $0.287^{*}$ & $0.513^{*}$ \\
CV\% & 19.357 & 24.037 & 20.195 \\
\hline
\end{tabular}

"Not significant CV: Coefficient of variation 
Previato do Amaral PFG, Otutumi LK, Rodrigues GV, Lima ET, Fernandes JIM, Vendrame A, Mezalira TS, Suenaga SS, Sestari DAO, Cestari IED, Martins LA

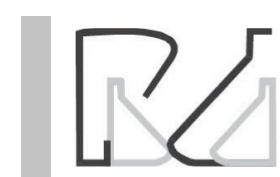

Assessment of Benzophenanthridine and Protopine Alkaloids in Broiler Challenged and Not by Salmonella Heidelberg
Table 6 - Median goblet cell counts in the cecal villi of 21-d-old broilers receiving or not benzophenanthridine and protopine alkaloids (BPA) in the drinking water, and challenged or not by Salmonella Heidelberg (SH) at six days of age.

\begin{tabular}{lc}
\hline Treatments & Median goblet cell count /villi \\
\hline Negative control & 20 \\
Positive Control & 14.5 \\
BPA 1-21d, SH & 13 \\
BPA 1-21d & 18 \\
BPA 1-6 d, SH & 17 \\
BPA 1-6 d & 12.5 \\
BPA 6-21d, SH & 17 \\
BPA 6-21d & 14 \\
\hline p value & $0.3090^{*}$ \\
CV\% & 30.79 \\
\hline
\end{tabular}

"Not significant by the Kruskal-wallis test.

CV: Coefficient of variation

conditions that may threat birds health, accelerating the intestinal transit and reducing nutrient absorption. In the present study, no evidences (clinical signs and/ or lesions) of the intestinal health damage in of birds challenged with Salmonella Heidelberg at six days of age were observed. The lack of significant differences $(p>0.05)$ in the expression of goblet cells indicates that the health challenge to which the birds were submitted in the present experiment was low, because the response depends on the invasiveness and level of aggression of the agent involved (Muniz, 2014).

According to Deplancke \& Gaskins (2001), the distribution of goblet cells and the mucus mucin composition vary both spatially and temporally; mucins may be acid (sulfated and non-sulfated) or neutral. Acidic mucin protects the intestine against bacterial translocation, because bacterial glycosidases are sensitive to $\mathrm{pH}$. The staining technique used in the present study for counting goblet cells was Alcian Blue $\mathrm{pH} 2.5$, expressing both sulfated and non-sulfated acid mucins.

In the present study, the broilers in treatments $T_{2^{\prime}} T_{3^{\prime}}$ $T_{5}$ and $T_{7}$ were challenged with Salmonella Heidelberg at six days of age. However, the microbiological analysis of the cloacal swab taken two days after the challenge showed that only $T_{7}$ (ABP 1-6, SH) birds were positive for Salmonella spp., and at 21 days, no birds in the challenged groups were positive. These results suggest that the intestinal colonization of Salmonella Heidelberg was not sufficient to cause any damage.

Salmonella spp. counts in the cecal samples of 8-d-old broilers (Table 7) were not significantly different among treatments.
Table $7-\log _{10}$ of the means \pm standard error of of Salmonella spp. counts (CFU/mL) in cecal samples of 8-d-old broilers receiving or not benzophenanthridine and protopine alkaloids (BPA) in the drinking water, and challenged or not by Salmonella Heidelberg (SH) at six days of age.

\begin{tabular}{ll}
\hline Treatments & CFU/mL $\left(\right.$ Log $\left._{10}\right)$ \\
\hline Negative control & $1.605 \pm 1.049$ \\
\hline Positive Control & $2.999 \pm 0.202$ \\
BPA 1-21d, SH & $3.340 \pm 1.188$ \\
BPA 1-21d & $0.706 \pm 0.706$ \\
BPA 1-6 d, SH & $3.553 \pm 0.737$ \\
BPA 1-6 d & $2.292 \pm 0.793$ \\
BPA 6-21d, SH & $1.631 \pm 0.989$ \\
BPA 6-21d & $2.587 \pm 0.775$ \\
\hline p value & $0.2852^{*}$ \\
\hline "Not significant by the Analysis of Variance (ANOVA).
\end{tabular}

The detection of Salmonella spp. in the experimental birds may be related to the fact that Salmonella spp. is a common inhabitant of the intestine of broilers, as described Muniz (2014). Pickler et al. (2013) reported that, although benzophenanthridine and protopine alkaloids did not reduce Salmonella Enteritidis counts in the excreta of broilers 48 hours after inoculation, counts significantly decreased in cecal samples seven days after inoculation. Santiago et al. (2014) also observed a significant difference in Salmonella Typhimurium counts, but only in the group of broilers that were challenged and were not fed BPA, differently from the present study, where no significant differences were observed between the challenged and not challenged groups and that received or not BPA in drinking water.

A study performed by Dzink \& Socransky (1985) previously demonstrated the antimicrobial activity and defined the minimum inhibitory concentrations of BPA against bacteria in the human mouth. As many of these bacterial species are also present in the gastrointestinal tract of broilers, these alkaloids could also be used to control poultry, as reported by Pickler et al. (2013) and Santiago et al. (2014). However, it is important to emphasize that the serotypes evaluated in the studies of Pickler et al. (2013) and Santiago et al. (2014) were Enteritidis and Typhimurium, respectively, differently from the present study. Furthermore, according to Borsoi et al. (2011), broilers challenged with Salmonella Heidelberg excrete less bacteria than those challenged with Salmonella Enteritidis. In addition, they present intermittent excretion of Salmonella Heidelberg (Borsoi, 2009), which may limit the efficiency of cloacal swabs as a diagnostic method 
Previato do Amaral PFG, Otutumi LK, Rodrigues GV, Lima ET, Fernandes JIM, Vendrame A, Mezalira TS, Suenaga SS, Sestari DAO, Cestari IED, Martins LA

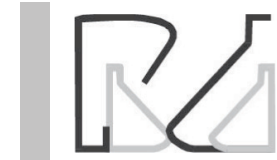

Assessment of Benzophenanthridine and Protopine Alkaloids in Broiler Challenged and Not by Salmonella Heidelberg and justify the low number of cloacal swab samples positive for Salmonella spp. obtained in 8-d-old broilers challenged with Salmonella Heidelberg.

\section{CONCLUSIONS}

Under the conditions of the present experiment, there was no effect of the addition of benzophenanthridine and protopine alkaloids in the drinking water of broilers challenged or not with Salmonella Heidelberg on performance parameters, jejunal morphometry, cecal goblet cell counts, or Salmonella spp. control. However, it is worth noting that the production efficiency index of broilers receiving the alkaloids from one to 21 days of age presented a numerical difference of more than 28 points compared with the control group, which directly impacts production costs of live broiler, and represents $\mathrm{R} \$ 0.11 / \mathrm{kg}$ meat produced savings, which justifies the use of benzophenanthridine and protopine alkaloids.

\section{ACKNOWLEDGEMENTS}

The authors thank the University Paranaense UNIPAR, Federal University of Parana - Sector Palotina - PR and the Executive Board of Directors for the Management of Research and Post-Graduation (Diretoria Executiva de Gestão da Pesquisa e da Pós Graduação - DEGPP ) at University Paranaense for the financial support, to CAPES for granting PROSUP scholarship, to Phytobiotics, to the Mercolab Laboratory and Cobb-Vantress for their support, incentive and contribution to the development of this research project.

\section{REFERENCES}

Almeida, PM. Estudo da presença de Salmonella spp. e parasitos gastrintestinais nas excretas de aves ornamentais de criadores da cidade de Umuarama , Paraná [dissertação]. Umuarama (PR): Universidade Paranaense; 2013.

Borsoi A. Inoculação de Salmonella Heidelberg e Salmonella Enteretidis em pintos de corte para avaliação da morfometria cecal, invasibilidade, persistência de excreção fecal e o uso de ácidos orgânicos e óleos essenciais no controle da Salmonella Enteretidis [dissertação]. Porto Alegre (RS): Universidade Federal do Rio Grande do Sul; 2009

Borsoi A, Santos LR, Rodrigues LB, Moraes HLS, Salle CTP, Nascimento VP. Behavior of Salmonella Heidelberg and Salmonella Enteritidis strains following broiler chick inoculation: evaluation of cecal morphometry, liver and cecum bacterial counts and fecal excretion patterns. Brazilian Journal of Microbiology, 2011;42(1):266-273.

Brasil. Ministério da Agricultura Pecuária e Abastecimento. Instrução Normativa $n^{\circ}$ 62/ 2003, que estabelece Métodos Analíticos Oficiais para Análises Microbiológicas para Controle de Produtos de Origem Animal e Água. Diário Oficial da União da República Federativa do Brasil; 2003.
Cobb-Vantress. Manual de manejo de frango de corte. Guapiaç: Avicultura Inteligente; 2009

Cook RH, Bird FH. Duodenal villus area and epithelial cellular migration in convention and germ-free chicks. Poultry Science 1973;52:2276-2280.

Council of the European Union. Food safety: additives for use in animal nutrition. Proceedings of the $24^{\circ}$ Council Meeting; 2003; Bruxelas. Bélgica.

Cury HS. Avaliação de aditivos na água de bebida para controle de Salmonella enterica subespécie Enterica Sorovar Heidelberg em frangos de corte [dissertação]. Curitiba (PR): Universidade Federal do Paraná; 2013

Deplancke B, Gaskins HR. Microbial modulation of innate defense: goblet cells and the intestinal mucus layer. The American Journal of Clinical Nutrition 2001:73:1131-41

Dršata J, Ulrichová J, Walterová D. Sanguinarine and chelerythrine as inhibitors of aromatic amino acid decarboxylase. Journal Enzyme Inhibition 1996;10(1):231-7.

Dzink JL, Socransky SS. Comparative in vitro activity of sanguinarina against oral microbial isolates. Antimicrobial Agents and Chemotherapy $1985 ; 27(4): 663-5$

Ferreira AK, Silva GX, Olmos AR, Bortolini TCK, Freitas DM, Coneglian JLB, et al. Avaliação de Sangrovit em dieta vegetariana para frangos de corte : avaliação dos efeitos com ácidos orgânicos. Anais do $18^{\circ}$ Salão de Iniciação Científica; 2006; Porto Alegre, Rio Grande do Sul. Brasil. p. 1

Gava MS. Metodologia de morfometria intestinal em frangos de corte [dissertação]. Porto Alegre (RS): Universidade Federal do Rio Grande do Sul; 2012.

Guidotti M. Aditivos fitogênicos na alimentação de aves de produção Revisão de literatura [seminário]. Goiânia (GO): Universidade Federa de Goiás; 2011

Griggs JP, Jacob JP. Alternatives to antibiotics for organic poultry production The Journal of Applied Poultry Research 2005;14(4):750-756.

Hernández F, Madrid J, Garcia V, Orengo J, Megias MD. Influence of two plant extracts on broilers performance, digestibility, and digestive organ size. Poultry Science 2004;83(2):169-74.

Jankowski J, Zduńczyk Z, Juśkiewicz J, Kozłowski K, Lecewicz A, Jeroch $H$. Gastrointestinal tract and metabolic response of broilers to diets with the Macleaya cordata alkaloidextract. Archivfür Geflügelkunde 2009;73(2):95-101

Kosina P, Walterova D, Ulrichova J, Lichnovsky V,Stiborova M, Rydlova $H$, et al. Sanguinarine and chelerythrine: assesment of safety on pigs in ninety days feeding experiment. Food and Chemical Toxicology 2004;42(1):85-91

Lanzarin MA. Importância e controle da contaminação por Salmonella spp e Clostridium perfringens em alimentos para aves. Chacabuco: Engormix; 2012

Macari, M. Fisiologia do sistema digestivo das aves (I). Aves e Ovos 1999;8/9:2-20.

Muniz EC. Salmonelas paratíficas em aves: avaliação da resposta imunológica e controle por meio de probióticos [dissertação]. Curitiba (PR): Universidade Federal do Paraná; 2014

Nascimento VP, Oliveira JD, Ribeiro AR, Santos LR, Cardoso MO, Pontes AP et al. Identificação de sorovares de Salmonella em cortes e carcaças de frango. Anai do $19^{\circ}$ Congresso Brasileiro de Microbiologia; 1997; Rio de Janeiro, RJ. Brasil. p. 287. 
Previato do Amaral PFG, Otutumi LK,

Rodrigues GV, Lima ET, Fernandes JIM,

Vendrame A, Mezalira TS, Suenaga SS

Sestari DAO, Cestari IED, Martins LA

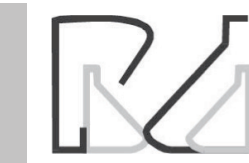

Assessment of Benzophenanthridine and Protopine Alkaloids in Broiler Challenged and Not by Salmonella Heidelberg
National Health Surveillance Agency. Metodologia dos testes de sensibilidade a agentes antimicrobianos por diluição para bactéria de crescimento aeróbico: Norma Aprovada. $6^{\mathrm{a}}$ ed. NCCLS 2003;23(2):910.

Niewold TA. The nonantibiotic anti-inflammatory effect of antimicrobial growth promoters, the real mode of action? A hypothesis. Poultry Science 2007;86(4):605-9.

Oliveira JP. Avaliação de óleos essenciais, extratos vegetais e óleos funcionais em dietas de frangos de corte [dissertação]. Curitiba (PR): Universidade Federal do Paraná; 2012.

Pickler L. Ácidos orgânicos via água e via ração para controlar Salmonella entérica Enterica Sorovares enteritidis e Minnesota em frangos [dissertação]. Curitiba (PR): Universidade Federal do Paraná; 2011.

Pickler L, Miglino L, Beirão BCB, Lourenço MC, Hayashi RM, Caron LF, et al. Alcalóide quaternário de benzofenantridina na expressão de células CD3+, células caliciformes na mucosa intestinal e células imunológias no sangue de frangos. Anais do $22^{\circ}$ Congresso Latino-Americano de Avicultura; 2011; Buenos Aires. Argentina: Associação Latinoamericana de Avicultura; 2011.

Pickler L, Hayashi RM, Lourenco MC, Miglino LB, Caron LF, Beirao BCB, et al. Avaliação microbiológica, histológica e imunológica de frangos de corte desafiados com Salmonella Enteritidis e Minnesota e tratados com ácidos orgânicos. Pesquisa Veterinária Brasileira 2012;32(1):2736.

Pickler L, Beirão BCB, Hayashi RM, Durau JF, Lourenço MC, Caron LF, et al. Effect of sanguinarine in drinking water on Salmonella control and the expression of immune cells in peripheral blood. The Journal of Applied Poultry Research 2013;22(3):430-438.

Rezende CSM, Mesquita AJ, Andrade MA, Linhares GFC, Mesquita AQ, Minafra CS. Sorovares de Salmonella isolados de carcaças de frangos de corte abatidos no Estado de Goiás, Brasil, e perfil de resistência a antimicrobianos. Revista Portuguesa de Ciências Veterinárias 2005;100(555/556): 199-203.
Santana ES, Mendes FR, Barnabé ACS, Oliveira FH, Andrade MA. Uso de produtos alternativos aos antimicrobianos na avicultura. Enciclopédia Biosfera 2011;7(13):985-1009.

Santin E, Maiorka A, Macari M, Grecco M, Sanchez JC, Okada TM, et al. Performance and intestinal mucosa development of broiler chickens fed diets containing Saccharomyces cerevisiae cell wall. The Journal of Applied Poultry Research 2001;10(3):236-44.

Santiago RA, Castillo AVR, Guerrero CLN, Aguirre SL, López JCG, Rodea $\mathrm{GB}$, et al. Evaluación del extracto de Macleaya Cordata en pollos de engorda. Anais do $24^{\circ}$ Congreso Panamericano de Ciencias Veterinarias; 2014; Havana. Cuba.

Schmeller T, Latz-Brüning B, Wink M. Biochemical activities of berberine, palmatine and sanguinarine mediating chemical defence against microorganisms and herbivores. Phytochemistry 1997;44(2):257-66.

Shivaprasad HL. Pullorum diseases and fowl typhoid. In: Calney BW, Barnes HJ, Beard CW, McDougald LR, Saif Y, editors. Diseases of poultry. 10th ed. Ames: lowa State University Press; 1997. p. 82-96.

Tarazi Fl, Moran-Gates T, Wong EHF, Henry B, Shahid M. Asenapine induces differential regional effects on serotonin receptor subtypes. Journal of Psychopharmacology 2010;24(3):341-348.

Vieira SL, Oyarzabal OA, Freitas DM, Berres J, Peña JEM, Torres, CA, et al. Performance of Broilers Fed Diets Supplemented with Sanguinarine and Organic Acids. The Journal of Applied Poultry Research 2008a;17(1):128-33.

Vieira SL, Berres J, Reis RN, Oyarzabal OA, Coneglian JLB, Freitas DM, et al. Studies with sanguinarine like alkaloids as feed additive in broiler diets. The Brazilian Journal of Poultry Science 2008b;10(1):67-71.

Zdunczyk Z, Gruzauskas R, Juskiewicz J, Semaskaite A, Jankowski J, Godycka-Klos I, et al. Growth performance, gastrointestinal tract responses, and meat characteristics of broiler chickens fed a diet containing the natural alkaloid sanguinarine from Macleaya cordata. The Journal of Applied Poultry Research 2010;19(4):393-400. 
